\title{
Prognostic Factors after Liver Resection for Colorectal Liver Metastasis
}

\author{
Factores de Prognóstico após Ressecção de Metástases Hepáticas de Cancro \\ Colo-Rectal
}

\author{
Margarida MATIAS $\triangle^{1}$, Mafalda CASA-NOVA¹, Mariana FARIA ${ }^{1}$, Ricardo PIRES ${ }^{2}$, Joana TATO-COSTA², Leonor \\ RIBEIRO ${ }^{1}$, Luís COSTA ${ }^{1}$ \\ Acta Med Port 2015 May-Jun;28(3):357-369
}

\begin{abstract}
Introduction: Surgery is the only potentially curative treatment for patients with colorectal liver metastases, resulting in 5-year survival rates of $36-58 \%$. Although many studies have been performed to determine prognostic factors for tumor recurrence and survival after resection of colorectal liver metastases, there are few prognostic scoring systems stratifying patients undergoing surgery for colorectal liver metastases into risk group models.

Objectives: To identify, evaluate and compare the existing prognostic scores for survival after surgery for resection of colorectal liver metastases.

Material and Methods: Electronic search in PubMed, Cochrane and Embase from 1990 to 2013 using the terms 'hepatic resection', 'colorectal cancer', 'liver metastasis', 'hepatectomy', 'prognostic', and 'score'. Only studies proposing a prognostic model or risk stratification based on clinical and/or pathological variables were included.

Results: From 1996 to June 2013, 19 scoring systems were identified, including one nomogram. Thirty prognostic factors were identified although none of the factors was common to all prognostic models. The 4 factors most often included were: number of liver metastases, regional lymph node metastization of primary tumor, preoperative CEA level and maximum size of metastases. The median study sample size was 305 patients (81-1 568 patients) and median follow-up was 33 months (16-54 months). All studies were retrospective and used the Cox proportional hazards model for multi-variable analysis.

Conclusion: Several factors have been constantly reported as having prognostic value after liver resection of colorectal liver metastases, although there is no consensus on the ideal scoring system.
\end{abstract}

Keywords: Colorectal Neoplasms; Hepatectomy; Liver Neoplasms/secondary; Liver Neoplasms/surgery; Prognosis.

\section{RESUMO}

Introdução: A ressecção de metástases hepáticas é o único tratamento potencialmente curativo em doentes com metástases hepáticas de cancro colo-rectal, resultando numa sobrevida global de 36-58\%. Até à data foram publicados múltiplos trabalhos sobre factores de prognóstico após hepatectomia em doentes com metástases hepáticas de cancro colo-rectal. No entanto, poucos apresentaram modelos de prognóstico que permitam estratificar os doentes em grupos de risco, relacionando-os com sobrevida após metastasectomia hepática.

Objectivos: Identificar, avaliar e comparar os diferentes scores de prognóstico após recessão de metástases hepáticas de cancro colo-rectal.

Material e Métodos: Pesquisa na PubMed, Cochrane e Embase, de artigos publicados entre 1990 e 2013, usando os termos 'recessão hepática', 'cancro colo-rectal', 'metástases hepáticas', 'hepatectomia', 'prognóstico' e 'modelo'. Apenas os artigos que apresentaram modelos de prognóstico com base em variáveis clínico-patológicas foram incluídos.

Resultados: De 1996 a Junho de 2013, 19 modelos de prognóstico foram identificados, incluindo um nomograma. Foram identificados 30 diferentes factores prognósticos, embora nenhum factor fosse comum a todos os modelos prognósticos. Os factores mais frequentemente incluídos foram: número de metástases hepáticas, envolvimento ganglionar regional do tumor primário, nível sérico de CEA pré-operatório e tamanho máximo das metástases. A amostra mediana foi de 305 doentes (81-1 568 doentes) e o seguimento mediano foi de 33 meses (16-54 meses). Todos os estudos foram retrospectivos e utilizaram o modelo proporcional de Cox para análise multivariada.

Conclusão: Vários factores têm sido constantemente reportados como tendo valor prognostico após ressecção de metástases hepáticas de cancro colorectal, no entanto, não existe consenso sobre o modelo ideal de prognóstico.

Palavras-chave: Hepatectomia; Neoplasias Colo-rectais; Neoplasias Hepáticas/cirurgia; Neoplasias Hepáticas/secundárias; Prognóstico.

\section{BACKGROUND}

Colorectal cancer (CRC) is the third most common tumor in men and the second in women, accounting for $10 \%$ of all tumor types worldwide. ${ }^{1}$ An increasing incidence of CRC has been observed in countries where the overall risk of large bowel cancer was low, while in historically highrisk countries either a decrease (USA, Canada and New

Zealand) or stabilization (Western Europe and Australia) has been reported. ${ }^{1,2}$

In Europe, colorectal cancer (CRC) is the third most frequent cancer in the 27 countries of the European Union (EU), after breast and prostate, accounting for $13 \%$ of all cancer and is the second most frequent cause of death after

\footnotetext{
1. Department of Medical Oncology. Centro Hospitalar Lisboa Norte. Lisbon. Portugal.

2. Clinical and Translational Research Oncology Unit. Instituto de Medicina Molecular. Lisbon. Portugal.

$\bowtie$ Autor correspondente: Margarida Matias. Margaridamatias.onc@gmail.com

Recebido: 01 de Setembro de 2013 - Aceite: 16 de Outubro de 2014 | Copyright @ Ordem dos Médicos 2015
} 
lung cancer. ${ }^{3,4}$

In 2012, new cancer cases in Europe were estimated to be 342137 (almost 1000 patients per day), comprising 191620 males (56\%) and 150514 females (44\%). The proportion of rectal cancer cases is variable depending on the cancer registry and classification of recto-sigmoid tumors, ranging from $27 \%$ to $58 \%$. $^{3,5}$

The estimated number of deaths caused by CRC was 149984, comprising $53 \%$ males and $47 \%$ females. . $^{3,4}$

A considerable variation among different EU countries has been observed. The highest incidence of CRC among males is observed in central European countries compared to very low rates in Greece and Cyprus. Among females, the EU countries with the highest incidence are Denmark and the Netherlands and the lowest incidence in Greece and Finland. Concerning mortality, the variability among countries is lower than variability in incidence, probably related to differences in stage of presentation and management strategies between countries. ${ }^{3}$

A gradient of increasing incidence and mortality due to CRC between North Western and South Eastern Europe has been observed. The growing incidence of $C R C$ in historically low-risk areas, such as Spain and Eastern Europe reflects modifications in lifestyle behaviors and their consequences such as obesity, high red meat consumption, heavy alcohol consumption, smoking and physical inactivity. ${ }^{1}$

In Europe, since the 1980s, survival has markedly improved. From 1980 until 2000-2002, five-year survival for all patients increased from $51 \%$ to $60 \%$ in northern Europe; from $52 \%$ to $62 \%$ in western European and from $45 \%$ to $58 \%$ in southern European registries. ${ }^{3}$

The relative increase in survival was $2 \%$ higher among females than among males across all registries. In general, improvement in survival was lower among patients with 75 years or older. ${ }^{3}$

Concerning stage at diagnosis, almost no progress in survival was observed among patients diagnosed with metastatic disease, while a markedly improvement in survival was observed among patients diagnosed in local or regional disease..$^{3,5}$

CRC screening has been shown to be effective in reducing mortality of the population aged $55-74$ years and possibly incidence as well. A Cochrane review showed a relative reduction of $16 \%$ in the risk of $C R C$ death using fecal occult blood tests (FOBT) every 2 years. ${ }^{3,6}$ Over the last few years, randomized trials have shown convincing evidence of the efficacy of flexible sigmoidoscopy in reducing the incidence and mortality from CRC. $3,7,8$

Decrease in mortality can be attributed, not only to CRC screening ${ }^{9,10}$ with consequent removal of adenomas, early detection of pre-cancerous and cancerous lesions, as well as the availability of more effective therapies, mainly for early stage disease. ${ }^{1}$

Surgical resection is the most effective therapy for metastatic colorectal cancer limited to the liver. Several studies from major centers have demonstrated that resection of as much as $80 \%$ of the liver can be performed with an associated surgical mortality rate uniformly less than $5 \% .{ }^{11-17}$

Surgery is the only potentially curative treatment for patients with colorectal liver metastases (CRLM), with studies suggesting an overall 5-year survival rate of 36$58 \%$ in contemporary series. ${ }^{18-25}$

Many studies have been performed to determine prognostic factors for tumor recurrence and survival after liver resection of CRLM. Nevertheless, only a few studies have presented prognostic scoring systems stratifying patients with CRLM submitted to surgery into risk group models which allow optimal clinical management of each patient.

\section{OBJECTIVES}

The aim of this review is to identify, evaluate and compare the existing prognostic scores that evaluate prognostic factors involved in the patient's outcome after liver resection for colorectal liver metastasis.

\section{MATERIAL AND METHODS}

An electronic search initially using the PubMed database, and later complemented by Cochrane and Embase databases was performed using the terms ('prognostic' OR 'prognosis') AND ('factors' OR 'factor' OR 'score' OR 'model') AND ('CRC' OR 'colorectal') AND ('metastasis' OR 'metastatic') AND ('liver resection' OR 'hepatic resection' OR 'hepatectomy').

Were found 1706 articles. Articles published before 1990 (128) were excluded. After analyzing the study abstracts, 194 articles concerning animal studies were excluded. Articles written in other languages than English, French, Spanish and Portuguese were excluded $(n=230)$. All case reports were also excluded $(n=205)$. The selection of the articles was performed by the first author of this study.

From the remaining 949 studies, all studies considered irrelevant for the subject or those analyzing prognostic factors (after resection of CRLM) but not presenting a scoring system, or including patients with unresectable disease were also excluded $(n=921)$. From the selected studies both abstracts and full text were analyzed.

One study ${ }^{26}$ that compared 2 clinical risks scores and TNM score, but did not present a new model, was also excluded. Studies that presented an external validation of prognostic scores were also excluded $(n=6)$. One study ${ }^{27}$ performed an external validation of 5 different prognostic models with the same population.

Two studies presented scoring systems as part of the analyzed prognostic factors, namely Glasgow Prognostic Score (GPS) ${ }^{28}$ and modified Glasgow Prognostic Score (mGPS). ${ }^{29}$ These 2 scores took into account the elevation of C-reactive protein (CRP of $>10 \mathrm{mg} / \mathrm{L}$ ) and hypoalbuminemia $(<35 \mathrm{~g} / \mathrm{L})$. However, as these studies evaluated both GPS and mGPS as one of the studied variables, and did not present a newer prognostic score, they were not included in the present study.

Finally, 19 different studies that presented a prognostic 
model or risk stratification based on clinical, laboratorial and/or pathological variables were included in this study. (Fig. 1)

The selected articles were analysed (both abstract and full text article). Extracted and analysed data were: year of the study, authors and corresponding centre, number of patients included in each study, number of centres included, period of the study (years), median follow-up of patients (months), endpoint of the study, total number of prognostic factors tested, number and type of independent prognostic factors included in each prognostic score, risk groups evaluated in each prognostic score, 5-years overall survival after resection and type of validation of the score (internal/ external).

Data were analysed using Excel $2010^{\text {TM }^{2}}$ and STATA ${ }^{\text {TM }}$.

\section{RESULTS}

Several studies have correlated demographic, clinical and pathological factors with survival after hepatectomy in patients with CRLM. However, there are few studies that have presented prognostic scoring systems. To our knowledge only 2 review articles about scoring systems have been published analyzing a fewer number of scoring systems. ${ }^{30,31}$

Between January 1996 and June 2013, we identified 19 scoring systems, including 1 nomogram developed by

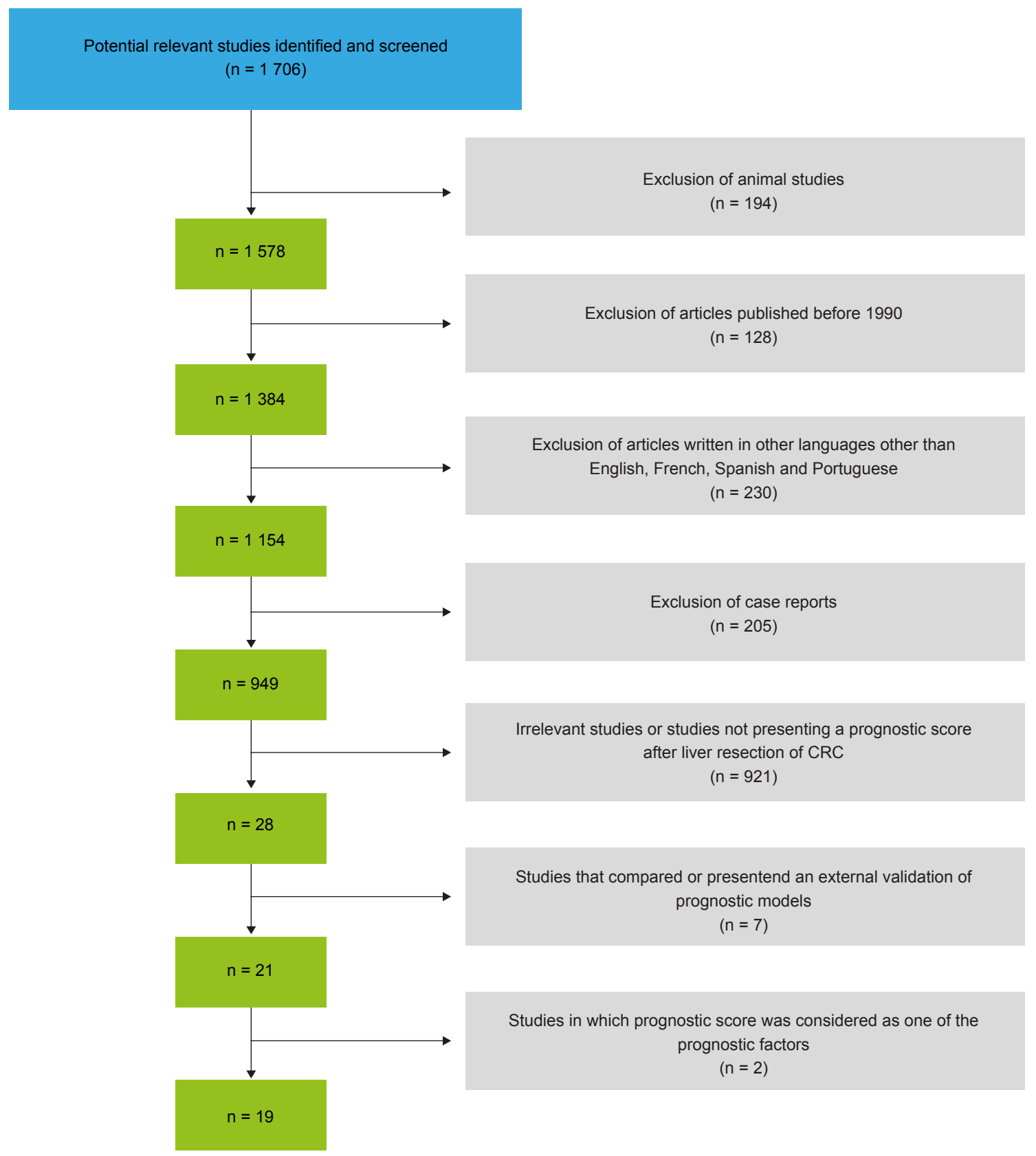

Figure 1 - Diagram representing the systematic selection of articles concerning predictive models for outcomes after liver resection of CRC liver metastasis. 


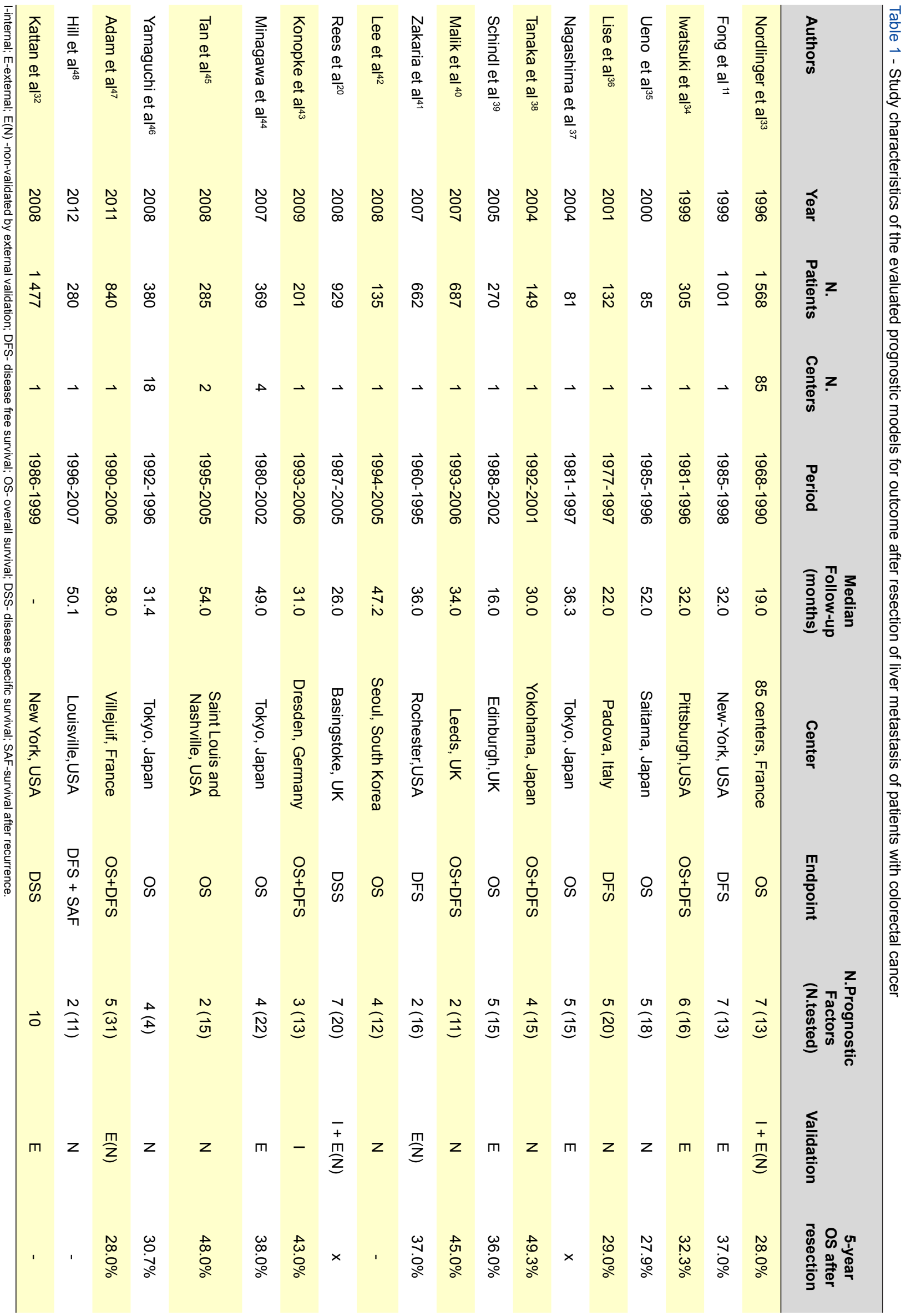


Kattan et al, ${ }^{32}$ concerning factors that influence survival after surgery of CRLM. (Table 1)

Seven scoring systems were proposed from European institutions (UK $=3$, France $=2$, Italy $=1$, Germany $=1$ ), 6 from Asian (Japan $=5$, South Korea $=1$ ) and 6 from North American institutions (USA $=6$ ) centers. The median study sample size was 305 patients (range 81-1568 patients) and the median follow-up was 33 months (range 16-54 months). All studies were retrospective in nature and the numbers of groups proposed by the various scoring systems ranged from three to six. All studies used the Cox proportional hazards model for multi-variable analysis.

All prognostic scoring systems were analyzed and prognostic factors, as well as risk group categories included in each model are described in Table 2.

\section{Prognostic factors}

From the 18 prognostic scores and one nomogram presented, 30 factors that independently influenced prognosis factors after surgery of CRLM were identified (Table 3).

The most cited factor was the number of liver metastases, identified by 15 different studies ${ }^{11,20,32-37,39,40,42-44,46,47}$ as a negative prognostic factor. Only four studies ${ }^{38,41,45,48}$ did not present it as a negative prognostic factor of survival after resection of CRLM.

Twelve studies referred lymph node positivity for the primary tumor as a negative prognostic factor. ${ }^{11,20,32,33,35-37,39,42,44-46}$

Nevertheless, six studies ${ }^{34,38,40,41,47,48}$ concluded that regional lymph node metastases of primary tumor was not a significant prognostic factor for survival. This fact was supported by other studies not included in the analysis. ${ }^{50-55}$ Thus, the prognostic value of lymph node spread of primary tumor remains controversial.

Preoperative elevation of CEA was pointed in nine studies as a negative prognostic factor. ${ }^{11,20,32,39,42-44,47,48}$ However, different studies used different cut-offs ranging from five ${ }^{42}$ to $200 \mathrm{ng} / \mathrm{mL} .{ }^{11,43,48}$ Nine studies concluded that preoperative elevation of CEA is not significant as a prognostic factor after resection of CRLM. ${ }^{33,35-37,40,41,45}$

Maximum size of hepatic metastases was indicated as a prognostic factor in eight studies ${ }^{11,20,32,33,34,37,41,46}$ and was considered without importance in 8 other studies. $35,36,38-40,42-45,47,48$

Extrahepatic disease (EHD) was considered a poor prognostic factor in seven of the nine prognostic scores that evaluated this parameter. ${ }^{11,20,34,37,46-48}$ In the majority of the analyzed studies patients with EHD were excluded from the analysis as many authors consider EHD a negative prognostic factor being considered as a contraindication for surgery of liver metastases in many institutions. Recently, studies have shown the contrary ${ }^{56,57}$; that isolated lung metastases when surgically resectable are no longer a contraindication for surgery and long-term survival can be archived with complete resection. ${ }^{31,47,57}$ Adam et al, ${ }^{47}$ developed a prognostic score for patients with resected
CRLM and concomitant extrahepatic disease (EHD) submitted to surgery and concluded that the five negative prognostic factors for survival of this group of patients were: EHD-location other than lung metastases, EHD concomitant to CRLM recurrence, CEA $\geq 10 \mathrm{ng} / \mathrm{mL}, \geq 6$ liver metastases, and right colon cancer. Therefore, patients with CRLM with metachronous diagnosis of EHD, with $<6$ liver metastases at diagnosis, presenting with isolated lung metastases and a CEA level $<10 \mathrm{ng} / \mathrm{mL}$, and in whom the primary tumor is not located in the right colon, had a good long-term survival after complete resection of disease, and were considered optimal candidates for this treatment strategy. Taking into account that surgery of all resectable disease is the best chance of long-term survival, whenever technically possible, surgery should be discussed. However, in an external validation of the referred prognostic model made by Mavros et $a l,{ }^{25}$ none of these factors reached statistical significance, and only EHD other than isolated lung metastases was found to independently predict overall survival.

As for EHD, the presence of positive margins has also been considered, by many authors, as a poor prognostic factor being excluded from analysis in the majority of studies. In only six studies, positive margins were analyzed, being considered as a poor prognostic factor in three ${ }^{11,20,34}$ of the six studies. In 2010 , Poultsides GA et al ${ }^{60}$ published a revision article about the impact of the surgical margin on the outcome after hepatic resection of colorectal metastases. The authors evaluated multiple studies that have specifically examined the role of a microscopically positive margin on overall survival and reported that, with the exception of one recent report, ${ }^{61}$ all previous studies ${ }^{11,62-66}$ have demonstrated consistently that a microscopically positive R1 margin is strongly correlated with worse overall survival. Concerning the optimal size of surgical margin, Poultsides GA et al ${ }^{62}$ concluded that, although an $\mathrm{R} 1$ resection should clearly be avoided, the actual margin width of an $\mathrm{R} 0$ resection does not impact on outcome after resection of CRLM. As such, failure to comply with the $1 \mathrm{~cm}$ rule can no longer be considered a contraindication for the surgical resection of CRLM.

There is a wide range in the cut-off interval of time between surgery for primary tumor and diagnosis of hepatic metastases ranging from $12^{11,35}$ to 30 months. ${ }^{34}$ Six studies ${ }^{11,32,33,34,35,41}$ considered the interval between the surgery for the primary colorectal tumor and the diagnosis of liver metastases as a prognostic factor, and six other studies $^{37,40,43,44,47,48}$ did not find statistically relevance of this factor.

Bilobar spread was considered a poor prognostic factor in only three studies, ${ }^{32,34,38}$ while in 11 other studies it was considered without importance. 11,20,33,35,37,39,41,43-45,47

Poor differentiation of primary tumor was considered a negative prognostic variable in only three studies ${ }^{20,38,45}$ while in four other studies ${ }^{34,35,39,44}$ it was not significantly associated with outcome.

Two studies ${ }^{33,37}$ suggested that serosal invasion of primary tumor was a negative prognostic factor while two others studies did not find any difference. ${ }^{35,38}$ 
Table 2 - Prognostic factors, Risk-group, score and 5-years OS evaluated in each scoring system

\begin{tabular}{|c|c|c|c|c|}
\hline Authors & Independent prgnostic factors & Groups & Score & Outcome (5 years) \\
\hline \multirow[t]{6}{*}{ Nordlinger et $\mathrm{al}^{33}$} & Age $\geq 60$ years & Low risk $(n=305)$ & $0-2$ & 2 year $-79 \%$ \\
\hline & Serosal invasion of primary tumor & Intermediate Risk $(\mathrm{n}=738)$ & $3-4$ & $60 \%$ \\
\hline & Node-positive primary & High risk $(n=230)$ & $5-7$ & $43 \%$ \\
\hline & Liver metastasis $<2$ years & & & \\
\hline & Liver metastasis $\geq 4$ & & & \\
\hline & $\begin{array}{l}\text { Margin } \leq 1 \mathrm{~cm} \\
\text { Metastasis size } \geq 5 \mathrm{~cm}\end{array}$ & & & \\
\hline \multirow[t]{6}{*}{ Fong et $\mathrm{al}^{11}$} & Margin envolved & $0(n=52)$ & 0 & $60 \%$ \\
\hline & Extra-hepatic disease & $1(n=262)$ & 1 & $44 \%$ \\
\hline & Node-positive primary & $2(n=350)$ & 2 & $40 \%$ \\
\hline & Liver metastais $<1$ year & $3(n=243)$ & 3 & $20 \%$ \\
\hline & Metastasis size $\geq 5 \mathrm{~cm}$ & $4(n=80)$ & 4 & $25 \%$ \\
\hline & $\begin{array}{l}\text { CEA }>200 \mathrm{ng} / \mathrm{ml} \\
\text { Liver metastasis }>1\end{array}$ & $5(n=14)$ & 5 & $14 \%$ \\
\hline \multirow[t]{7}{*}{ Iwatsuki et al ${ }^{34}$} & Liver metastases $\geq 2$ & Grade $1(n=32)$ & 0 & $48 \%$ \\
\hline & Metastasis size $\geq 8 \mathrm{~cm}$ & Grade $2(n=112)$ & 1 & $34 \%$ \\
\hline & Bilobar distribution & Grade $3(n=47)$ & 2 & $18 \%$ \\
\hline & $\begin{array}{l}\text { Interval between colorectaland liver } \\
\text { resection } \leq 30 \text { months }\end{array}$ & Grade $4(n=47)$ & 3 & $6 \%$ \\
\hline & Margin involved & Grade $5(n=5)$ & 4 & $1 \%$ \\
\hline & Extrahepatic disease & Grade $6(n=62)$ & $\mathrm{R} 1$ & $0 \%$ \\
\hline & & & EHD & \\
\hline \multirow[t]{3}{*}{ Ueno et $\mathrm{al}^{35}$} & $\begin{array}{l}\text { Primary site aggressiveness (marked } \\
\text { tumour budding /node-positive) }\end{array}$ & Group A $(n=30)$ & $\begin{array}{l}\mathrm{H}-\mathrm{A} 0 \text { or either liver } \\
\text { metast }<1 \text { year or } \geq \\
3 \text { liver met }\end{array}$ & 3-year: 80\% \\
\hline & Liver metastasis < 1 year & Group B $(n=46)$ & $\begin{array}{l}\text { H-B Primary site } \\
\text { aggres or both liver } \\
\text { metast }<1 \text { year and } \\
\geq 3 \text { liver met }\end{array}$ & $55 \%$ \\
\hline & Liver metastases $\geq 3$ & Group C $(n=9)$ & $\mathrm{H}-\mathrm{C}-\mathrm{All} 3$ factors & $10 \%$ \\
\hline \multirow[t]{5}{*}{ Lise et $\mathrm{al}^{36}$} & $>30 \%$ liver invasion & Group A $(n=38)$ & $0-2$ & 3-year: $80 \%$ \\
\hline & Node-positive primary & Group B $(n=36)$ & $3-5$ & $55 \%$ \\
\hline & Liver metastasis > 1 & Group C $(n=58)$ & $\geq 6$ & $10 \%$ \\
\hline & GPT levels $\geq 55 \mathrm{U} / \mathrm{l}$ & & & \\
\hline & Non-anatomical resection & & & \\
\hline \multirow[t]{5}{*}{ Nagashima et $\mathrm{al}^{37}$} & Serosal invasion of primary tumor & Grade A $(n=28)$ & $0-1$ & $85 \%$ \\
\hline & Node-positive primary & Grade B $(n=14)$ & $2-3$ & $56 \%$ \\
\hline & Resectable extrahepatic disease & Grade $C(n=13)$ & $>3$ & $0 \%$ \\
\hline & Liver metastasis > 1 & & & \\
\hline & Metastasis size $5 \mathrm{~cm}$ & & & \\
\hline
\end{tabular}


Table 2 - Prognostic factors, Risk-group, score and 5-years OS evaluated in each scoring system (continued)

\begin{tabular}{|c|c|c|c|c|}
\hline Authors & Independent prgnostic factors & Groups & Score & Outcome ( 5 years) \\
\hline \multirow[t]{4}{*}{ Tanaka et $a^{38}$} & $\begin{array}{l}\text { Poorly-dif. ADC or mucinous carc. } \\
\text { (Poor/muc) }\end{array}$ & Stage I $(n=55)$ & 0 factors & $61.1 \%$ \\
\hline & Marked vascular invasion (V) & Stage II $(n=67)$ & $\begin{array}{l}\text { bi-lobular met or } \\
\text { short DT }\end{array}$ & $51.3 \%$ \\
\hline & Bi-lobular liver metastasis & Stage III $(n=20)$ & $\begin{array}{l}2 \text { factors and/or } \\
\text { marked vascular } \\
\text { invasion }\end{array}$ & $\begin{array}{l}0 \% \text { (mean survival } \\
780 \mathrm{~d} \text { ) }\end{array}$ \\
\hline & $\begin{array}{l}\text { Short doubling time (DT) of the liver } \\
\text { tumor }\end{array}$ & Stage IV $(n=7)$ & Poor/muc & $\begin{array}{l}0 \% \text { (mean survival } \\
257 \mathrm{~d} \text { ) }\end{array}$ \\
\hline \multirow[t]{5}{*}{ Schindl et al. ${ }^{39}$} & Duke's stage C & & & \\
\hline & CEA level & Good $(n=33)$ & $0-10$ points & 60 months \\
\hline & Alkaline phosphatase & Moderate $(n=172)$ & $11-25$ points & 32 months \\
\hline & Albumin & Poor $(n=65)$ & $>25$ points & 22 months \\
\hline & Liver metastasis $>3$ & & & \\
\hline \multirow[t]{3}{*}{ Malik et al ${ }^{40}$} & $\begin{array}{l}\text { Inflammatory response } \\
(\mathrm{CRP}>10 \mathrm{mg} / \mathrm{L} \text { or Neut/Linf }>5: 1)\end{array}$ & $0(n=382)$ & 0 factors & $49 \%$ \\
\hline & Liver metastases $\geq 8$ & $1(n=155)$ & 1 factors & $34 \%$ \\
\hline & & $2(n=23)$ & 2 factors & $0 \%$ \\
\hline \multirow[t]{4}{*}{ Zakaria et al ${ }^{41}$} & Blood transfusion & Group 1 & 0 & $55 \%$ \\
\hline & Positive hepatoduodenal nodes (HDN) & Group 2 & Blood transfusion & $39 \%$ \\
\hline & Liver metastasis $\leq 30$ months & Group 3 & HDN & $20 \%$ \\
\hline & Metastasis size $\geq 8 \mathrm{~cm}$ & (Note: $\mathrm{n}$ was not stated) & & \\
\hline \multirow[t]{4}{*}{ Lee et $\mathrm{al}^{42}$} & Margin $\leq 5 \mathrm{~mm}$ & Low risk $(n=85)$ & $0-1$ & $46 \%$ \\
\hline & $\mathrm{CEA}>5 \mathrm{ng} / \mathrm{ml}$ & Intermediate risk $(n=36)$ & 2 & $41 \%$ \\
\hline & Node-positive primary $\geq 4$ & High risk $(n=14)$ & $3-4$ & $11 \%$ \\
\hline & Liver metastases $>1$ & & & \\
\hline \multirow[t]{7}{*}{ Rees et $\mathrm{al}^{20}$} & Liver metastases $>3$ & & & Preop \\
\hline & Node-positive primary & 0 & 0 & $66 \%$ \\
\hline & Poorly differentiated primary & $1-5$ & $1-5$ & $51 \%$ \\
\hline & Extrahepatic disease & $6-10$ & $6-10$ & $35 \%$ \\
\hline & Metastasis size $\geq 5 \mathrm{~cm}$ & $11-15$ & $11-15$ & $21 \%$ \\
\hline & $\mathrm{CEA}>60 \mathrm{ng} / \mathrm{ml}$ & $>15$ & $>15$ & $2 \%$ \\
\hline & Margin involved & (n was not stated) & & \\
\hline
\end{tabular}

The prognostic relevance of hepatic lymph node metastases was only evaluated in two studies, ${ }^{41,44}$ and both suggested a negative prognostic value.

Age of 60 years or more was referred by Nordlinger et $\mathrm{al}^{33}$ as a negative prognostic factor. Age was also included in the nomogram developed by Kattan et al. ${ }^{32}$

Some factors have been pointed as negative prognostic factors in only one prognostic score: marked tumour budding (defined as micro-tubular cancer nests or microscopic clusters of undifferentiated cancer cells) was presented by Ueno et $\mathrm{al}^{35}$ short doubling time of the liver tumor and marked vascular invasion were identified only in the study by Tanaka et al. ${ }^{38}$

Synchronous liver metastases was identified as a negative prognostic factor for survival by Konopke et al. ${ }^{43}$ More than $30 \%$ of liver invasion and non-anatomical resection were only referred by Lise et $\mathrm{al}^{36}{ }^{36}$ and surgical margin $\leq 5 \mathrm{~mm}$ by Lee et $\mathrm{al}^{42}$ while extensive resection 
Table 2 - Prognostic factors, Risk-group, score and 5-years OS evaluated in each scoring system (continued)

\begin{tabular}{|c|c|c|c|c|}
\hline Authors & Independent prgnostic factors & Groups & Score & Outcome (5 years) \\
\hline \multirow[t]{4}{*}{ Konopke et $\mathrm{al}^{43}$} & Liver metastasis $\geq 4$ & & & Median survival: \\
\hline & Synchronous liver metastases & Low risk $(n=112)$ & 0 & 67 months \\
\hline & $C E A \geq 200 \mathrm{ng} / \mathrm{ml}$ & Intermediate risk $(n=74)$ & 1 & 47 months \\
\hline & & High risk $(n=15)$ & 2 & 38 months \\
\hline \multirow[t]{5}{*}{ Minagawa et $\mathrm{al}^{44}$} & hepatic lymph node metastasis & & & $\begin{array}{l}\text { Median survival } \\
\text { (original cohort) }\end{array}$ \\
\hline & $\geq 4$ colorectal lymph node metastasis & stage $1(n=78)$ & 0 & 7.2 years \\
\hline & $\mathrm{CEA}>50 \mathrm{ng} / \mathrm{ml}$ & stage $2(n=129)$ & 1 & 3.5 years \\
\hline & multiple hepatic metastasis & stage $3(n=111)$ & $2-3$ & 2.0 years \\
\hline & & stage $4(n=4)$ & $\begin{array}{l}\text { hepatic lymph node } \\
\text { metastasis }\end{array}$ & 1.3 years \\
\hline \multirow[t]{3}{*}{ Tan et $\mathrm{al}^{45}$} & $\begin{array}{l}\text { Tumor Grade (Poorly vs well or } \\
\text { moderately-differenciated) }\end{array}$ & Poor Dif. $(n=44)$ & Poor Dif. & not referend \\
\hline & Lymph Node (positive vs negative) & $\begin{array}{l}\text { Well } / \text { mod. dif. }+ \text { node } \\
\text { negative }(n=86)\end{array}$ & $\begin{array}{l}\text { Well/mod. dif. + node } \\
\text { negative }\end{array}$ & not referend \\
\hline & & $\begin{array}{l}\text { Well } / \text { mod. dif. }+ \text { node } \\
\text { positive }(n=122)\end{array}$ & $\begin{array}{l}\text { Well/mod. dif. + node } \\
\text { positive }\end{array}$ & not referend \\
\hline \multirow[t]{4}{*}{ Yamaguchi et al ${ }^{46}$} & $\geq 5$ liver metastasis & Stage A & $\mathrm{HT} 1+\mathrm{pN} 0 / 1+\mathrm{EM} 0$ & $53.50 \%$ \\
\hline & Largest liver metastasis $\geq 5 \mathrm{~cm}$ & Stage B & $\begin{array}{l}(\mathrm{HT} 2+\mathrm{PN} 0-1 \text { or } \mathrm{HT} 2 \\
+\mathrm{pN} 0-1)+\mathrm{EM} 0\end{array}$ & $25.40 \%$ \\
\hline & $\geq 4$ mesenteric lymph node metastasis & Stage C & HT3 or EM1 & $5.80 \%$ \\
\hline & Extrahepatic metastasis & (n was not stated) & & \\
\hline \multirow{6}{*}{ Adam et $\mathrm{al}^{47}$} & EHD other than isolated lung metastasis & $0(n=8)$ & 0 & $64 \%$ \\
\hline & $C E A \geq 10 \mathrm{ng} / \mathrm{ml}$ & $1(n=44)$ & 1 & $25.6-43.9 \%$ \\
\hline & $>5$ liver metastasis & $2(n=60)$ & 2 & $4.9-22.2 \%$ \\
\hline & Right colon as the primary CRC location & $3(n=45)$ & 3 & $0.2-4.0 \%$ \\
\hline & $\begin{array}{l}\text { Diagnosis of EHD concomitant to CRLM } \\
\text { recurrence }\end{array}$ & $4(n=11)$ & 4 & $0-0.1 \%$ \\
\hline & & $5(n=2)$ & 5 & $0 \%$ \\
\hline
\end{tabular}

(lobectomy or more) was included on the nomogram by Kattan et al. ${ }^{32}$

Other negative prognostic factors included on the evaluated scoring systems were: serum concentration of alkaline phosphatase and albumin, referred by Schindl et al, ${ }^{39} \mathrm{GPT}$ levels $\geq 55 \mathrm{U} / \mathrm{l}$ referred by Lise et al, ${ }^{36}$ inflammatory response (defined by an elevated C-reactive protein (> 10 $\mathrm{mg} / \mathrm{L}$ ) or a neutrophil/lymphocyte ratio of $>5: 1$ ), stated by Malik et al, ${ }^{40}$ and necessity of blood transfusion pointed by Zakaria et al. ${ }^{41}$

Right colon as the primary colorectal location and diagnosis of extrahepatic disease concomitant to CRLM recurrence were identified by Adam et al $^{47}$ as poor prognostic factors in patients with extrahepatic disease undergoing resection of CRLM. However, as previously stated, in an external validation of the referred prognostic model made by Mavros et $a{ }^{25}$ none of these factors reached statistically significance, and only EHD other than isolated lung metastases was found to independently predict overall survival.

The unique prognostic score that proposed the pattern of recurrence as a poor prognostic factor for survival after recurrence was developed by Hill et al. ${ }^{48}$

Gender and primary cancer site (colon versus rectum) were also included in the nomogram developed by Kattan et al. ${ }^{32}$

None of the studies included chemotherapy as a prognostic factor because of its failure to achieve statistical significance. Nevertheless, Konopke et $\mathrm{al}^{43}$ pointed that, in the subgroup of high-risk patients, neoadjuvant chemotherapy improved the survival of the patients who underwent both chemotherapy and resection compared with those who underwent resection only. In the future, prognostic scores could be useful in selecting patients who 
Table 2 - Prognostic factors, Risk-group, score and 5-years OS evaluated in each scoring system (end)

\begin{tabular}{|c|c|c|c|c|}
\hline Authors & Independent prgnostic factors & Groups & Score & Outcome (5 years) \\
\hline \multirow[t]{6}{*}{ Hill et al ${ }^{48}$} & After recurrence Prognostic Factors: & 1 & & Median OS \\
\hline & CEA $>200 \mathrm{ng} / \mathrm{ml}$ (= 2 points $)$ & $2-3$ & 1 & $49.9 \mathrm{M}$ \\
\hline & Pattern of recurrence & $4-5$ & $2-3$ & $29.6 \mathrm{M}$ \\
\hline & Liver only or lung only (= 1 point) & (n was not stated) & $4-5$ & $22.0 \mathrm{M}$ \\
\hline &.$E H D$ or liver and lung only ( $=2$ points) & & & \\
\hline & EHD and liver (= 3 points) & & & \\
\hline
\end{tabular}

After Hepatectomy:

$\mathrm{CEA}>200 \mathrm{ng} / \mathrm{ml}$

$>1$ metastasis

High Fong score

Kattan et al ${ }^{32} \quad$ Nomogram

Nodal status of the primary tumor

Disease-free interval

Size of the largest metastatic tumor

Preoperative CEA

Bilateral resection

Extensive resection (lobectomy or more)

Gender

Number of hepatic tumors

Primary cancer site (colon vs rectum)

Age

$\mathrm{HT} 1=(\leq 4$ liver metastasis and largest liver metastasis $\leq 5 \mathrm{~cm}), \mathrm{HT} 2=\geq 5$ liver metastasis or largest liver metastasis $>5 \mathrm{~cm})$; HT3 $=(\geq 5$ liver metastasis and largest liver metastasis $>5 \mathrm{~cm}), \mathrm{pNO} / 1=\leq 3$ mesenteric lymph node metastasis, pN2 = $\geq 4$ mesenteric lymph node metastasis, EM1 = presence of extrahepatic metastases, EM0 = absence of extrahepatic metastases, EHD = Extrahepatic disease, DSS = Disease Specific Survival, SAF survival after recurrence; HDN - positive hepatoduodenal nodes

would benefit from neoadjuvant or adjuvant chemotherapy.

Currently, the only nomogram for predicting diseasesurvival after segmental hepatic resection for CRLM, was developed by Kattan et $\mathrm{al}^{32}$ following analyses of all patients admitted to Memorial Sloan-Kettering Cancer Center (MSKCC) for curative intent for treatment of metastatic disease from CRC between 1986 and 1999. A nomogram was developed as a graphical representation of a Cox proportional hazards regression model, using as prognostic factors: nodal status of the primary tumor, disease-free interval, size of the largest metastatic tumor, preoperative CEA, bilateral resection, extensive resection (lobectomy or more), gender, number of hepatic tumors, primary cancer site (colon vs rectum), and age. The advantage of the nomogram is that, rather than counting risk factors, it takes the specific value for each factor into consideration. For example, instead of considering a preoperative
CEA value above 200 to be a risk factor, the nomogram considers the patient's actual CEA value, and calculates risk accordingly, being more specific to the individual patient and thus predicting more accurately. In order to compare the prediction ability of the nomogram, Kattan et al $^{32}$ applied the clinical risk score (CRS) developed by Fong et al. ${ }^{11}$ When refit to those patients used in the original CRS, the nomogram predicted more accurately than did the Fong score when applied to the same validation set.

Later on, in 2013, Reddy et al ${ }^{49}$ presented an external validation of this nomogram using an external cohort of 203 patients who underwent resection of CRLM between 1996 and 2006. After a median follow-up of 30.4 months, KaplanMeier estimates for 3, 5 and 8-year post-resection DSS were $56 \%, 41 \%$, and $32 \%$, respectively; similar to nomogram predicted probabilities for disease specific survival (DSS). The concordance index for the nomogram was higher 


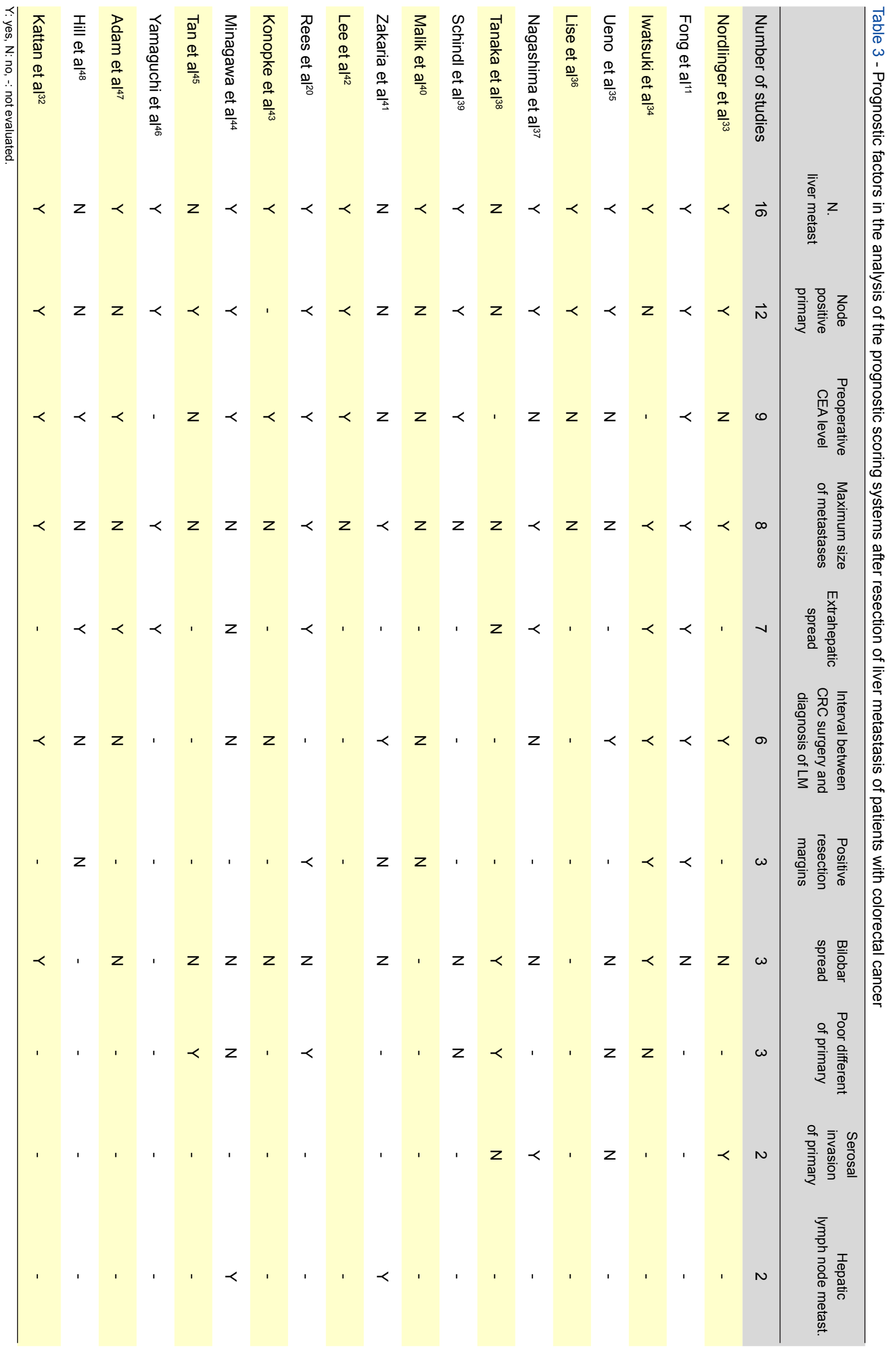


(0.602) than for the Fong colorectal risk score (CRS; 0.533). Therefore, the CRLM nomogram was validated by an external cohort and more accurately predicted postresection survival than the commonly used CRS.

\section{Endpoints}

Not all studies had overall survival (OS) as the endpoint. Some studies had disease-free survival (DFS) ${ }^{11,36,42}$ as endpoint and some had both OS and DFS $34,38,40,43,47$ Hill et $\mathrm{al}^{48}$ had as endpoints DFS and survival after recurrence while Kattan et $\mathrm{al}^{32}$ and Rees et al ${ }^{20}$ had disease specific survival (DSS).

\section{Validation of models}

Before prognostic scores can be widely implemented, it is very important their validation. The validation of a model can be internal or external. The majority of the prognostic scores was not validated.

The models developed by Nordlinger et al, ${ }^{33}$ Rees et $\mathrm{al}^{20}$ and Konopke et $\mathrm{al}^{43}$ underwent internal validation while models presented by Nagashima et al, ${ }^{37}$ Schindl et al ${ }^{39}$ and Minagawa et al. ${ }^{44}$ underwent external validation. The model presented in 2008 by Kattan et al ${ }^{32}$ was validated in 2009 by Reddy et $\mathrm{al}^{49}$ with an unrelated cohort from a different institution. The external validation concluded that the CRLM nomogram more accurately predicted post-resection survival than the commonly used CRS developed by Fong et al. ${ }^{11}$

The model presented by Adam et $\mathrm{al}^{47}$ was externally validated by Mavros et al. ${ }^{25}$ However the authors concluded that of the 5 proposed risk factors, only EHD other than isolated lung metastases was found to independently predict overall survival. A study presented by Reissfelder et al $^{27}$ performed an external validation with 281 patients of 5 different prognostic scoring systems for patients undergoing resection of colorectal cancer liver metastases: Nordlinger score ${ }^{33}$ MSKCC score, ${ }^{11}$ Iwatsuki score, ${ }^{34}$ Basingstoke index, (Rees et al) ${ }^{20}$ and Mayo scoring system (Zacaria et al). ${ }^{41}$ They concluded that only MSKCC score ${ }^{11}(p=0.006)$ and the Iwatsuki score ${ }^{34}(p=0.01)$ provided a statistically significant stratification of patients with regard to survival.

\section{DISCUSSION}

\section{Limitations of the prognostic scoring systems}

The ideal prognostic score has not yet been defined. All prognostic scores presented have some limitations.

All the studies proposing prognostic scores were retrospective studies. Some studies reported patients submitted to surgery in 1970 and 1980 decades. Since then, much progress has been achieved, not only in surgical techniques, but also, in the anesthesia and pre and post-operative care. Due to this progress, surgical related morbidity and mortality has been decreased in the last decades.

Selection of variables has changed a lot between different prognostic scores. While some variables were pointed as negative factors in many studies (number of liver metastases, node positive primary, preoperative CEA level, maximum size of metastases), some variables have been reported in only one prognostic score. Thus, the identification of the ideal scoring system remains controversial.

Another important aspect not correctly evaluated by these prognostic scoring systems is the importance of neoadjuvant and adjuvant chemotherapy. In the last 2 or 3 decades many agents have been approved and showed increase survival not only in the adjuvant, but also in the metastatic setting in the colorectal cancer treatment.

The median sample size is 305 patients, ranging from 81 to 1568 patients. Studies with smaller population may have greater risk of bias compared to studies including larger sample sizes.

As referred, the fact that almost all prognostic scoring systems had excluded extrahepatic disease and positive surgical margins of primary tumor, is another important limitation of the analysis because it is not possible to compare strictly different populations.

Another limitation was the fact that different studies had different endpoints, OS, DFS or DSS; and the limited number of studies that were validated. As referred in the results section, only few models were validated.

Thus, an important heterogeneity between studies has been observed, regarding studied population, exclusion criteria, quality of methodology, evaluated prognostic factors, time of follow-up, endpoints, among others.

\section{Clinical application of scoring systems}

According to current guidelines, patients with colorectal liver metastases suitable for surgery should be offered surgery in order to resect all macroscopic disease with negative margins, leaving sufficient liver remnant. Surgery of CRLM is the only chance for cure and long-time survival of these patients. ${ }^{25,47}$ Thus, we have to be very cautious with the clinical application of these models, especially when deciding whether to perform surgery of resectable liver metastases of colorectal cancer.

Another important value of these scoring systems is the selection of the patients that can benefit from pre-operative or subsequent chemotherapy associated or not with a biological agent. The scoring system involving prognostic factors may influence the choice of the chemotherapy regimen, especially nowadays, when a lot of different and some recent agents both cytotoxic and target agents are available for the management of metastatic colorectal disease.

\section{CONCLUSION}

After an extended research on PubMed, Cochrane and Embase databases, only 19 prognostic models of clinical outcome of patients submitted to liver resection of colorectal liver metastasis were included in this revision.

Several factors have been constantly reported as having prognostic value after liver resection of CRLM. However, none of the evaluated factors were presented in all risk models. Although some models have been externally 
validated, there is yet no consensus on the ideal scoring system for the approach of patients with colorectal liver metastases suitable for surgery. Although the absence of consensus of the ideal scoring system, the nomogram developed by Kattan et $\mathrm{al}^{32}$ is undoubtedly a very practical and useful scoring system and should probably be considered when evaluating prognostic factors after liver resection for colorectal liver metastasis.

\section{PROTECTION OF HUMANS AND ANIMALS}

The authors declare that the procedures were followed according to the regulations established by the Clinical Research and Ethics Committee and to the Helsinki Declaration of the World Medical Association.

\section{REFERENCES}

1. Labianca R, Nordlinger B, Beretta GD, Mosconi S, Mandalà M, Cervantes A, et al. Early colon cancer: ESMO Clinical Practice Guidelines for diagnosis, treatment and follow-up. Ann Oncol. 2013;24:vi64-72.

2. Jemal A, Center M, deSantis C, Ward EM. Global patterns of cancer incidence and mortality rates and trends. Cancer Epidemiol Biomarkers Prev. 2010;19:1893-907.

3. Van de Velde CJ, Boelens PG, Borras JM, Coebergh JW, Cervantes A, Blomqvist L, et al. EURECCA colorectal: multidisciplinary management: European consensus conference colon \& rectum. Eur $\mathrm{J}$ Cancer. 2014;50:1.e1-34.

4. Ferlay J, Steliarova-Foucher E, Lortet-Tieulent J, Rosso S, Coebergh JW, Comber $\mathrm{H}$, et al. Cancer incidence and mortality patterns in Europe: estimates for 40 countries in 2012. Eur J Cancer. 2013;49:1374-403.

5. Brenner H, Bouvier AM, Foschi R, Hackl M, Larsen IK, Lemmens V, et al. Progress in colorectal cancer survival in Europe from the late 1980s to the early 21st century: the EUROCARE study. Int J Cancer. 2012;131:1649-58

6. Hewitson P, Glasziou P, Watson E, Towler B, Irwig L. Cochrane systematic review of colorectal cancer screening using the fecal occult blood test (hemoccult): an update. Am J Gastroenterol. 2008;103:15419.

7. Segnan N, Armaroli P, Bonelli L, Risio M, Sciallero S, Zappa M, et al. Once-only sigmoidoscopy in colorectal cancer screening: follow-up findings of the Italian Randomized Controlled Trial - SCORE. J Nat Cancer Inst. 2011;103:1310-22.

8. Atkin WS, Edwards R, Kralj-Hans I, Wooldrage K, Hart AR, Northover $\mathrm{JM}$, et al. Once-only flexible sigmoidoscopy screening in prevention of colorectal cancer: a multicentre randomized. Lancet. 2010;375:1624-33.

9. Schoen RE, Pinsky PF, Weissfeld JL, Yokochi LA, Church T, Laiyemo $\mathrm{AO}$, et al. Colorectal-cancer incidence and mortality with screening flexible sigmoidoscopy. N Engl J Med. 2012;366:2345-57.

10. Nishihara R, Wu K, Lochhead P, Morikawa T, Liao X, Qian ZR, et al. Long-term colorectal-cancer incidence and mortality after lower endoscopy. N Engl J Med. 2013;369:1095-105.

11. Fong $\mathrm{Y}$, Fortner J, Sun RL, Brennan MF, Blumgart LH. Clinical score for predicting recurrence after hepatic resection for metastatic colorectal cancer: analysis of 1001 consecutive cases. Ann Surg. 1999;230:309 18.

12. Scheele J, Stang R, Altendorf-Hofmann A, Paul M. Resection of colorectal liver metastases. World J Surg. 1995;19:59-71.

13. Gayowski TJ, Iwatsuki S, Madariaga JR, Selby R, Todo S, Irish W, et al. Experience in hepatic resection for metastatic colorectal cancer: analysis of clinical and pathological risk factors. Surgery. 1994;116:70311.

14. Rosen CB, Nagorney DM, Taswell HF, Helgeson SL, Ilstrup DM, van Heerden JA, et al. Perioperative blood transfusion and determinants of survival after liver resection for metastatic colorectal carcinoma. Ann Surg. 1992;216:492-505.

15. Nordlinger B, Parc R, Delva E, Quilichini M, Hannoun L, Huguet C. Hepatic resection for colorectal liver metastases. Ann Surg. 1987;205:256-63.

16. Hughes KS, Simons R, Songhorabodi S. Resection of the liver for colorectal carcinoma metastases: a multi-institutional study of

\section{DATA CONFIDENTIALITY}

The authors declare having followed the protocols in use at their working center regarding patient's data publication.

\section{CONFLICTS OF INTEREST}

The authors declare that there are no conflicts of interest.

\section{FUNDING SOURCES}

No subsidies or grants contributed to this work.

indications for resection. Surgery. 1988;103:278 -88.

17. Fong Y, Cohen AM, Fortner JG, Enker WE, Turnbull AD, Coit DG, et al. Liver resection for colorectal metastases. J Clin Oncol. 1997;15:938-46.

18. Morris EJ, Forman D, Thomas JD, Quirke P, Taylor EF, Fairley L, et al. Surgical management and outcomes of colorectal cancer liver metastases. Br J Surg. 2010;97:1110-18.

19. De Jong MC, Pulitano C, Ribero D, Strub J, Mentha G, Schulick RD, et al. Rates and patterns of recurrence following curative intent surgery for colorectal liver metastasis: An international multi-institutional analysis of 1669 patients. Ann Surg. 2009;250:440-8

20. Rees M, Tekkis PP, Welsh FK, O'Rourke T, John TG. Evaluation of longterm survival after hepatic resection for metastatic colorectal cancer: A multifactorial model of 929 patients. Ann Surg. 2008;247:125-35.

21. Wei AC, Greig PD, Grant D, Taylor B, Langer B, Gallinger S. Survival after hepatic resection for colorectal metastases: a 10-year experience. Ann Surg Oncol. 2006;3:668-76.

22. Fernandez FG, Drebin JA, Linehan DC, Dehdashti F, Siegel BA, Strasberg SM. Five-year survival after resection of hepatic metastases from colorectal cancer in patients screened by positron emission tomography with F-18 fluorodeoxyglucose (FDG-PET). Ann Surg. 2004;240:438-47.

23. Abdalla EK, Vauthey JN, Ellis LM, Ellis V, Pollock R, Broglio KR et al. Recurrence and outcomes following hepatic resection, radiofrequency ablation, and combined resection/ablation for colorectal liver metastases. Ann Surg. 2004;239:818-25.

24. Choti MA, Sitzmann JV, Tiburi MF, Sumetchotimetha W, Rangsin R, Schulick RD, et al. Trends in long-term survival following liver resection for hepatic colorectal metastases. Ann Surg. 2002;235:759-66.

25. Mavros MN, Hyder O, Pulitano C, Aldrighetti L, Pawlik TM. Survival of patients operates for colorectal liver metastasis and concomitant extrahepatic disease: external validation of a prognostic model. J Surg Oncol. 2013;107:481-5.

26. Merkel S, Bialecki D, Meyer T, Müller V, Papadopoulos T, Hohenberger W. Comparison of clinical risk scores predicting prognosis after resection of colorectal liver metastasis. J Surg Oncol. 2009;100:349-57.

27. Reissfelder C, Rahbari NN, Koch M, Ulrich A, Pfeilschifter I, Waltert A et al. Validation of prognostic scoring systems for patients undergoing resection of colorectal cancer liver metastases. Ann Surg Oncol. 2009;16:3279-88

28. Ishizuka M, Kita J, Shimoda M, Rokkaku K, Kato M, Sawada T, et al. Systemic inflammatory response predicts postoperative outcome in patients with liver metastasis from colorectal cancer. J Surg Oncol. 2009;100:38-42.

29. Nakagawa K, Tanaka K, Nojiri K, Kumamoto T, Takeda K, Ueda M, et al. The Modified Glasgow Prognostic Score as a predictor of survival after hepatectomy for colorectal liver metastases. Ann Surg Oncol. 2014;21:1711-8.

30. Gomez D, Cameron IC. Prognostic scores for colorectal liver metastasis: clinically important or an academic exercise? HPB. 2010;12:227-38.

31. Spelt L, Andersson B, Nilsson J, Andersson R. Prognostic models for outcome following liver resection for colorectal cancer metastases: A systematic review. Eur J Surg Oncol. 2012;38:16-24.

32. Kattan MW, Gönen M, Jarnagin WR, DeMatteo R, D'Angelica M, Weiser 
$M$, et al. A nomogram for predicting disease specific survival after hepatic resection for metastatic colorectal cancer. Ann Surg. 2008;247:282-7

33. Nordlinger B, Guiguet M, Vaillant JC, Balladur P, Boudjema K, Bachellier, $P$ et al. Surgical resection of colorectal carcinoma metastases to the liver. A prognostic scoring system to improve case selection, based on 1568 patients. Association Française de Chirurgie. Cancer. 1996;77:1254-62.

34. Iwatsuki S, Dvorchik I, Madariaga JR, Marsh JW, Dodson F, Bonham AC, et al. Hepatic resection for metastatic colorectal adenocarcinoma:a proposal of a prognostic scoring system. J Am Coll Surg. 1999;189:2919.

35. Ueno $\mathrm{H}$, Mochizuki $\mathrm{H}$, Hatsuse $\mathrm{K}$, Hase $\mathrm{K}$, Yamamoto T. Indicators for treatment strategies of colorectal liver metastases. Ann Sur. 2000;231:59-66.

36. Lise M, Bacchetti S, Da Pian P, Nitti D, Pilati P. Patterns of recurrence after resection of colorectal liver metastases: prediction by models of outcome analysis. World J Surg. 2001;25:638-44.

37. Nagashima I, Takada T, Matsuda K, Adachi M, Nagawa H, Muto T et al. A new scoring system to classify patients with colorectal liver metastases: proposal of criteria to select candidates for hepatic resection. J Hepatobiliary Pancreat Surg. 2004;11:79-83

38. Tanaka K, Shimada H, Fujii Y, Endo I, Sekido H, Togo S, et al. Prehepatectomy prognostic staging to determine treatment strategy for colorectal cancer metastases to the liver. Langenbecks Arch Surg. 2004;389:371-9

39. Schindl M, Wigmore SJ, Currie EJ, Laengle F, Garden OJ. Prognostic scoring in colorectal cancer liver metastases: development and validation. Arch Surg. 2005;140:183-9.

40. Malik HZ, Prasad KR, Halazun KJ, Aldoori A, Al-Mukhtar A, Gomez D, et al. Preoperative prognostic score for predicting survival after hepatic resection for colorectal liver metastases. Ann Surg. 2007;246:806-14.

41. Zakaria S, Donohue JH, Que FG, Farnell MB, Schleck CD, Ilstrup DM, et al. Hepatic resection for colorectal metastases: value for risk scoring systems? Ann Surg. 2007;246:183-91.

42. Lee WS, Kim MJ, Yun SH, Chun HK, Lee WY, Kim SJ, et al. Risk factor stratification after simultaneous liver and colorectal resection for synchronous colorectal metastasis. Langenbecks Arch Surg. 2008;93:13-9.

43. Konopke R, Kersting S, Distler M, Dietrich J, Gastmeier J, Heller A, et al. Prognostic factors and evaluation of a clinical score for predicting survival after resection of colorectal liver metastases. Liver Int. 2009;29:89-102.

44. Minagawa M, Yamamoto J, Kosuge T, Matsuyama $\mathrm{Y}$, Miyagawa S, Makuuchi M. Simplified staging system for predicting the prognosis of patients with resectable liver metastasis: development and validation. Arch Surg. 2007;142:269-76.

45. Tan MC, Castaldo ET, Gao F, Chari RS, Linehan DC, Wright JK, et al. A prognostic system applicable to patients with resectable liver metastasis from colorectal carcinoma staged by positron emission tomography with [18F] fluoro-2-deoxy-D-glucose: role of primary tumor variables. J Am Coll Surg. 2008;206:857-68

46. Yamaguchi T, Mori T, Takahashi K, Matsumoto H, Miyamoto H, Kato T. A new classification system for liver metastases from colorectal cancer in Japanese multicenter analysis. Hepatogastroenterology. 2008;55:1738.

47. Adam R, de Haas RJ, Wicherts DA, Vibert E, Salloum C, Azoulay D, et al. Concomitant extrahepatic disease in patients with colorectal liver metastasis: when is there a place for surgery? Ann Surg. 2011;253:34959.

48. Hill CR, Chagpar RB, Callender GG, Brown RE, Gilbert JE, Martin RC 2nd,et al. Recurrence following hepatectomy for metastatic colorectal cancer: development of a model that predicts patterns of recurrence and survival. Ann Surg Oncol. 2012;19:139-44.

49. Reddy SK, Kattan MW, Yu C, Ceppa EP, de la Fuente SG, Fong Y, et al. Evaluation of peri-operative chemotherapy using a prognostic nomogram for survival after resection of colorectal liver metastases, HPB. 2009;11:592-9.

50. Harms J, Obst T, Thorban S, Busch R, Fink U, Heidecke CD, et al. The role of surgery in the treatment of liver metastases for colorectal cancer patients. Hepatogastroenterology. 1999;46:2321-8.

51. Hohenberger P, Schlag PM, Gerneth T, Herfarth C. Pre- and postoperative carcinoembryonic antigen determinations in hepatic resection for colorectal metastases. Predictive value and implications for adjuvant treatment based on multivariate analysis. Ann Surg. 1994;219:135-43.

52. Sugihara K, Hojo K, Moriya $Y$, Yamasaki S, Kosuge T, Takayama T. Pattern of recurrence after hepatic resection for colorectal metastases. Br J Surg. 1993;80:1032-5.

53. Choti MA, Sitzmann JV, Tiburi MF, Sumetchotimetha W, Rangsin R, Schulick RD, et al. Trends in long-term survival following liver resection for hepatic colorectal metastases. Ann Surg. 2002;235:759-66.

54. Arru M, Aldrighetti L, Castoldi R, Di Palo S, Orsenigo E, Stella M, et al. Analysis of prognostic factors influencing long-term survival after hepatic resection for metastatic colorectal cancer. World J Surg. 2008;32:93103.

55. Sasaki A, Iwashita Y, Shibata K, Matsumoto T, Ohta M, Kitano S. Analysis of preoperative prognostic factors for long-term survival after hepatic resection of liver metastasis of colorectal carcinoma. J Gastrointest Surg. 2005;9:374-80.

56. Okano K, Yamamoto J, Kosuge T, Yamamoto S, Sakamoto M, Nakanishi $\mathrm{Y}$, et al. Fibrous pseudocapsule of metastatic liver tumors from colorectal carcinoma. Clinicopathologic study of 152 first resection cases. Cancer. 2000;89:267-75

57. Wei AC, Greig PD, Grant D, Taylor B, Langer B, Gallinger S. Survival after hepatic resection for colorectal metastases: a 10-year experience. Ann Surg Oncol. 2006;13:668-76.

58. Adam R. The importance of visceral metastasectomy in colorectal cancer. Ann Oncol. 2000;11:29-36.

59. Headrick JR, Miller DL, Nagorney DM, Allen MS, Deschamps C, Trastek VF, et al. Surgical treatment of hepatic and pulmonary metastases from colon cancer. Ann Thorac Surg. 2001;71:975-9.

60. Poultsides GA, Schulick RD, Pawlik TM. Hepatic resection for colorectal metastases: the impact of surgical margin status on outcome. HPB. 2010;12:43-9.

61. De Haas RJ, Wicherts DA, Flores E, Azoulay D, Castaing D, Adam R. $\mathrm{R} 1$ resection by necessity for colorectal liver metastases: is it still a contraindication to surgery? Ann Surg. 2008;248:626-37.

62. Steele G Jr, Bleday R, Mayer RJ, Lindblad A, Petrelli N, Weaver D. A prospective evaluation of hepatic resection for colorectal carcinoma metastases to the liver: Gastrointestinal Tumor Study Group Protocol 6584. J Clin Oncol. 1991;9:1105-12.

63. Cady B, Jenkins RL, Steele GD Jr, Lewis WD, Stone MD, McDermott $\mathrm{WV}$, et al. Surgical margin in hepatic resection for colorectal metastasis: a critical and improvable determinant of outcome. Ann Surg. 1998;227:566-71.

64. Choti MA, Sitzmann JV, Tiburi MF, Sumetchotimetha W, Rangsin R, Schulick RD, et al. Trends in longterm survival following liver resection for hepatic colorectal metastases. Ann Surg. 2002;235:759-66.

65. Pawlik TM, Scoggins CR, Zorzi D, Abdalla EK, Andres A, Eng C, et al. Effect of surgical margin status on survival and site of recurrence after hepatic resection for colorectal metastases. Ann Surg. 2005;241:71522.

66. Nuzzo G, Giuliante F, Ardito F, Vellone M, Giovannini I, Federico B, et al. Influence of surgical margin on type of recurrence after liver resection for colorectal metastases: a single-centre experience. Surgery. 2008;143:384-93. 
Margarida MATIAS, Mafalda CASA-NOVA, Mariana FARIA, Ricardo PIRES, Joana TATO-COSTA, Leonor RIBEIRO, Luís COSTA

\section{Prognostic Factors after Liver Resection for Colorectal Liver Metastasis}

Acta Med Port 2015:28:357-369

Publicado pela Acta Médica Portuguesa, a Revista Científica da Ordem dos Médicos

Av. Almirante Gago Coutinho, 151

1749-084 Lisboa, Portugal.

Tel: +351218428215

E-mail: submissao@actamedicaportuguesa.com

www.actamedicaportuguesa.com

ISSN:0870-399X | e-ISSN: 1646-0758

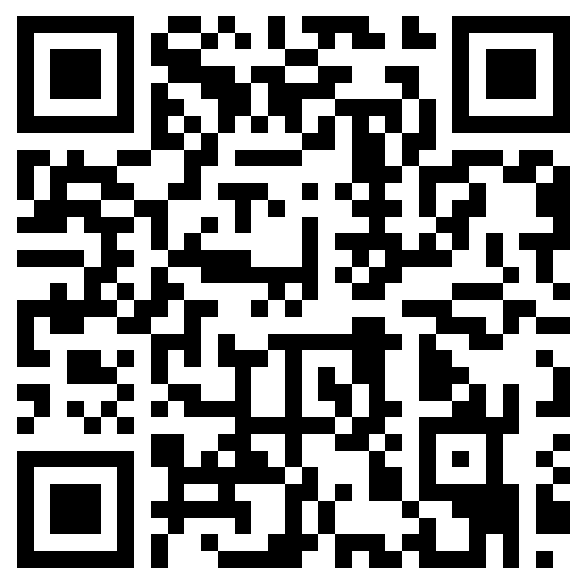

